\title{
JOB SATISFACTION OF ADMINISTRATIVE STAFF IN VIETNAMESE PUBLIC TECHNOLOGY UNIVERSITY
}

\author{
Pham Thi Kim Ngoc \\ Department of Management Science \& Law, \\ School of Economics and Management, \\ Hanoi University of Science and Technology, Hanoi, Vietnam \\ (Email: ngoc.phamthikim@hust.edu.vn)
}

Accepted date: 23-03-2019

Published date: 08-07-2019

To cite this document: Ngoc, P. T. K. (2019). Job Satisfaction of Administrative Staff in Vietnamese Public Technology University. International Journal of Modern Trends in Social Sciences, 2(8), 149-161.

DOI: $10.35631 / \mathrm{IJMTSS} .280015$

\begin{abstract}
Job satisfaction of employees has been attracted many researchers nowadays in general and in Vietnam in specific. Past researches on job satisfaction in Vietnam includes Dung (2005); Toan (2009); Anh (2010), Thuy (2011), and Ngoc (2013). However, there was not many research study on the job satisfaction of administrative staff at public university, especially in Vietnam. This research is to provide an in-depth of job satisfaction of administrative staff in Vietnamese public technology university and identifies the factors influencing on their job satisfaction. Both quantitative and qualitative research applied in this study. Findings of this research show that the job satisfaction of administrative staff is quite high in the public university in Vietnam. 7 factors influence including "Reward and discipline”, "Income ", "Supervisor", "Colleagues", "Working environment”, "Job characteristics", and "Benefits and welfare" on job satisfaction at these universities. Among these factors, "Working environment" has the strongest positive impact and the "Benefits and welfare" has the lowest positive impact on the job satisfaction of administrative staff at the public university. Some alternative solutions on improving the working environment, supervisor's feedback, fair payment system and training provided to administrative staff are suggested. Thanks to these solutions, the job satisfaction of administrative staff will be strengthened and the public universities will retain the engagement of their administrative staff.
\end{abstract}

Keywords: Job Satisfaction, Job Characteristics, Supervisor, Colleagues, Administrative Staff, Technology University in Vietnam

\section{Introduction}

Like many other countries in the world, education and training in Vietnam is on the way of modernization. Number of public universities was increased significantly from 101 public universities and colleges to more than 350 public universities and colleges in last decades (Trines, 2017). Education in Vietnam plays a vital role to provide the high quality and 
advance human resources that was a critical success factor in implementing the eco-social economy development strategy in 2011-2020 and to meet the needs of country industrialization in a global environment (https://wenr.wes.org/2017/11/education-invietnam).

In implementing the Vietnam's socio-economic development strategy, Vietnamese university should invest in these resources especially human resources. These universities need to study deeply the physical and non-physical demands and needs of both its direct (lecturers and researchers) and indirect workforce (administrative staff) in order to stimulate staff spirits for the best efforts. According to GSO (2017), administrative staff, who implements supportive and administrative services to overall operation of university, occupy about 25-30\% of total workforce in Vietnamese public university. Therefore, the urgent and important task at Vietnamese public universities is to stimulate administrative staff motivation and job satisfaction (Ngoc, 2019). Even, researches on motivation at work and job satisfaction of labor in business fields and lecturers in universities had conducted by many foreign and local authors such as Mangkunegara et al. (2015), Rafiq et al. (2012), Artz (2008), Ngoc et al. (2013), Thuy (2011), Anh (2010), Nhat (2009). Very few research on job satisfaction of administrative staff had been done in Vietnam (Toan, 2009; Ngoc, 2019). To fill the research gap, this research selected some public technology universities in Vietnam to do a survey on administrative staff's job satisfaction. This will enrich the picture of job satisfaction of administrative staff in public technology universities in Vietnam.

\section{Conceptual Framework}

Figure 1 shows the overall conceptual framework of this study. There are 7 steps including research objective identification, research model development, research design, questionnaire survey, data input and analysis, reliability and multi-regression analysis, and conclusion and recommendation.

\section{Figure 1. Research Conceptual Framework}

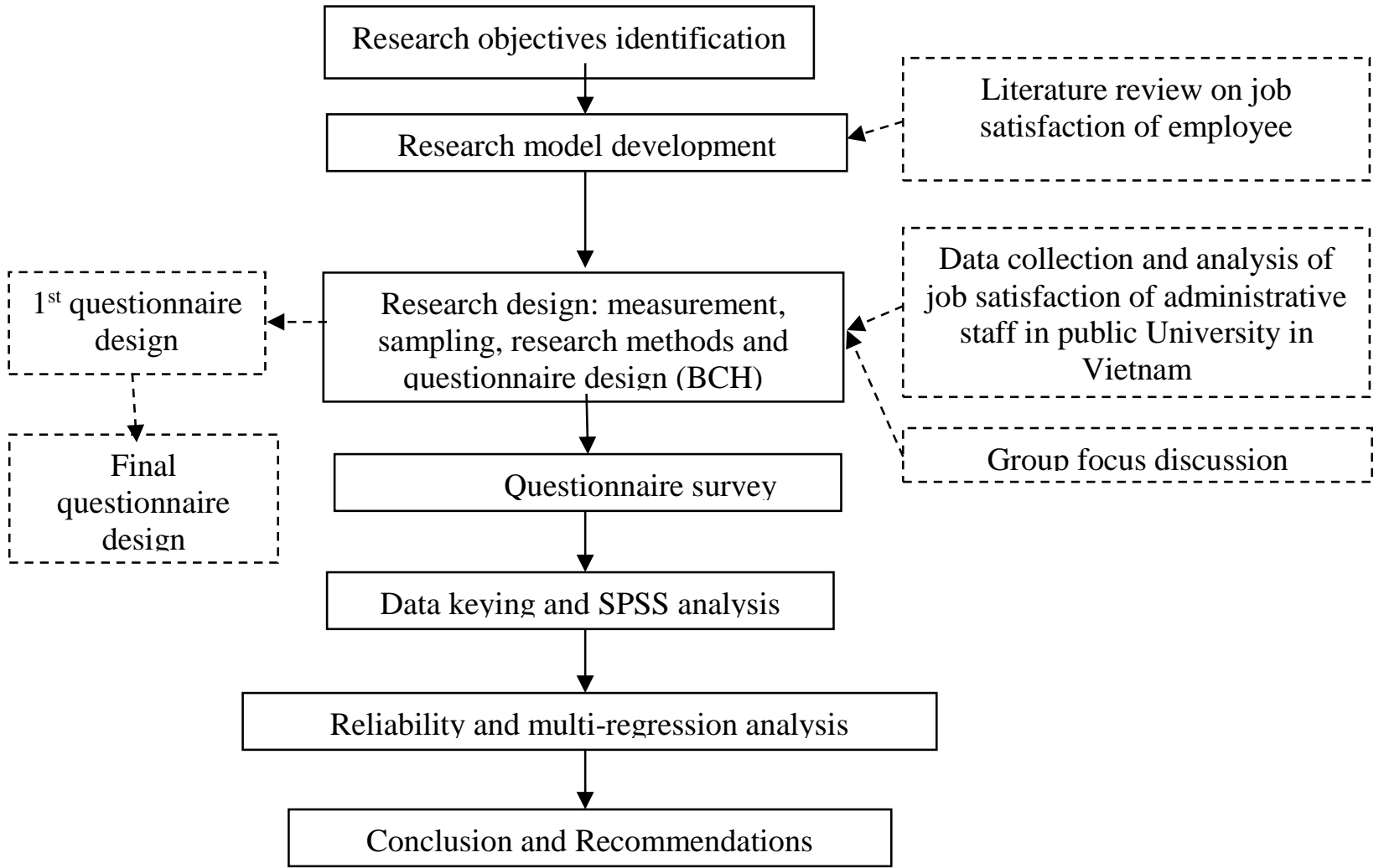




\section{Literature review}

\section{Definition of Job Satisfaction}

Job satisfaction term is defined in various ways. Classically, job satisfaction is understood as "...affective orientations on the part of individuals toward work roles they presently occupy" (Vroom, 1946) or as "the attitude to the work through the expression of the employee's feeling, trust and behaviour" (Weiss, 1967); as "a pleasurable or positive emotional state resulting from the appraisal of one's job or job experiences" (Locke, 1976). Recently, Ellickson and Logsdon (2001) defined job satisfaction is "the extent to which employees like their job, based on the perception of the employees (both positive and negative) about their work or working conditions". The more working conditions comply with the employee's needs, values and traits, the more employees are satisfied. Kreitner and Kinicki (2007) indicated job satisfaction shows "the level of how an individual likes his/her job" in another word, job satisfaction is truly "the emotion or feeling of that employee towards his work". In this research, the satisfaction of the admin staff is defined as "the extent that the admin staff like their job, feel comfortable and reflect positive attitudes towards all the aspects of their job".

\section{Components of Job Satisfaction}

According to Luddy (2005), job satisfaction components consisted of job position, control of supervisors, relationship with colleagues, job content, benefits including promotion, good physical working conditions as well as organizational structure. In a number of research studies in job satisfaction in USA and other countries, Andrew (2002) measured job satisfaction by 7 determinants including job security, working place, income, relationship with colleagues, traveling duration, public relation, training opportunities to improve employees' skills. In the research on different offices in Ho Chi Minh City, Toan (2009) measured the job satisfaction of admin staff with 7 variables: income, training and promotion, supervisors, colleagues, job characteristics, working conditions, company's welfare. Anh (2010) and Ngoc (2013) applied a model of 8 aspects: job nature, training and promotion, supervisor, salary, working environment, colleague, job appraisal, and welfare to study the job satisfaction of workers in construction industry. Whereas, Thuy (2011) surveyed the impacts on the job satisfaction of professors at universities in Ho Chi Minh City with a model of 5 components which are job, training and promotion, income, supervisors and colleagues. Table 1 illustrates all the components of the job satisfaction of selected research studies.

Table 1. Determinants of Job Satisfaction

\begin{tabular}{|l|l|l|l|l|l|l|}
\hline \multirow{2}{*}{ Factors } & \multicolumn{5}{|c|}{ Authors } \\
\cline { 2 - 7 } & $\begin{array}{l}\text { Andrew } \\
(2002)\end{array}$ & $\begin{array}{l}\text { Dung } \\
(2005)\end{array}$ & $\begin{array}{l}\text { Toan } \\
(2009)\end{array}$ & $\begin{array}{l}\text { Anh } \\
(2010)\end{array}$ & $\begin{array}{l}\text { Thuy } \\
(2011)\end{array}$ & Ngoc (2013) \\
\hline Job appraisal & & & & X & & X \\
\hline Job characteristics & & $\mathrm{X}$ & $\mathrm{X}$ & $\mathrm{X}$ & $\mathrm{X}$ & $\mathrm{X}$ \\
\hline Training and promotion & $\mathrm{X}$ & $\mathrm{X}$ & $\mathrm{X}$ & $\mathrm{X}$ & $\mathrm{X}$ & $\mathrm{X}$ \\
\hline Supervisor & & $\mathrm{X}$ & $\mathrm{X}$ & $\mathrm{X}$ & $\mathrm{X}$ & $\mathrm{X}$ \\
\hline Colleague & $\mathrm{X}$ & $\mathrm{X}$ & $\mathrm{X}$ & $\mathrm{X}$ & $\mathrm{X}$ & $\mathrm{X}$ \\
\hline Salary & & $\mathrm{X}$ & & $\mathrm{X}$ & & $\mathrm{X}$ \\
\hline Welfare & & $\mathrm{X}$ & $\mathrm{X}$ & $\mathrm{X}$ & & $\mathrm{X}$ \\
\hline Working environment & & $\mathrm{X}$ & $\mathrm{X}$ & $\mathrm{X}$ & & $\mathrm{X}$ \\
\hline
\end{tabular}




\begin{tabular}{|l|l|l|l|l|l|l|}
\hline Benefits & & & & & & \\
\hline Income & $\mathrm{X}$ & & $\mathrm{X}$ & & $\mathrm{X}$ & \\
\hline Working place & $\mathrm{X}$ & & & & & \\
\hline Job security & $\mathrm{X}$ & & & & & \\
\hline Travelling duration & $\mathrm{X}$ & & & & & \\
\hline Supervision & $\mathrm{X}$ & & & & & \\
\hline
\end{tabular}

\section{Hypotheses}

\section{Model 1: The Relationship Between Job Satisfaction and Its Components}

The research of Binh (2009) on the job satisfaction of the workers shows that the satisfaction of salary, co-workers, supervisor is positively correlated with that of the overall job. Similarly, Ngoc et al. (2013) identified that the supervisor, job characteristics, income, coworkers, reward and discipline prove a positive correlation with the overall job satisfaction. Based on the result of previous researches on the factors influencing on job satisfaction, the following hypotheses are developed:

H1: Job nature creates a positive impact on the job satisfaction of administrative staff in public university in Vietnam

H2: Reward and discipline create a positive impact on the job satisfaction of administrative staff in public university in Vietnam

H3: Supervisor has a positive impact on the job satisfaction of administrative staff in public university in Vietnam

H4: Colleagues have a positive impact on the job satisfaction of administrative staff in public university in Vietnam

H5: Working environment and conditions create a positive impact on the job satisfaction of administrative staff in public university in Vietnam

H6: Income creates a positive impact on the job satisfaction of administrative staff in public university in Vietnam

H7: Benefits and welfare create a positive impact on the job satisfaction of administrative staff in public university in Vietnam

\section{Model 2: Relationship Between Individual Personality and Job Satisfaction}

Research studies have shown that individual personality have impacts on the job satisfaction of the employee. Andrew (2002) conducted a research on job satisfaction in the US and other countries. His research measures that job satisfaction of women is higher than that of man and the job satisfaction is U-shaped in age. Whereas, the research of Tom (2007) results in the conclusion that unskilled worker has much lower job satisfaction $(33.6 \%$ of the respondents are satisfied with their current job) and those who are high-skilled possess quite high satisfaction level (55.8\% of the respondents). In Vietnam, Binh (2009) showed a different result, which concludes that job satisfaction of men is higher than that of women. In addition, the research of Dat (2009) for the job satisfaction of office employees found job position, seniority and the number of job changes contributes to higher job satisfaction. In her recent research, Anh (2010) found the higher the income of an employee, the higher the job satisfaction. This research proposes the following hypothesis on the relationship between individual personality and job satisfaction of the administrative staff in Vietnamese public university: 
H8: There is a difference in job satisfaction of administrative staff between genders in public university in Vietnam.

H9: There is a difference in job satisfaction of administrative staff by age in public university in Vietnam.

H10: There is a difference in job satisfaction of administrative staff by seniority in public university in Vietnam.

H11: There is a difference in job satisfaction of administrative staff by educational level in public university in Vietnam.

\section{Measurement}

The Dependent Variable of Job Satisfaction

In this research, job satisfaction of administrative staff in public universities is measured by using Michigan Organizational Assessment Questionnaire - Job Satisfaction Subscale (MOAQ-JSS):

a) I am satisfied with my job, overall

b) I like my current job, overall

The reliability of the measurement scale has been proven by many research studies which show a high Cronbach alpha between job variables. (Jex \& Gudanowski, 1992; Spector, 1988).

\section{Measurement of Independent Variables}

In consideration of the previous studies on job satisfaction, this research applied the following components to measure the job satisfaction of administrative staff at Vietnam public technology universities:

- Job characteristic: Hackman and Oldman (1974) described that the job which satisfies the employees and results in high performance has some characteristics: "application of different skills, deep understanding of job requirements and the job importance to the corporate's business, employee's authorities to accomplish his/her job and employee's responsibility for his/her decisions, and feedback from the supervisor".

- Reward and Discipline: Reward is an incentive that an employee received from the organization in return for his/her effort to the organization. Reward is either in the form of monetary or non-monetary. Many researches on the rewards found that rewards had a significant relation to job satisfaction and it became a key factor in determining job satisfaction of employees (Rafiq et al., 2012). Discipline of work is an effort of the management to implement or execute the rules or regulations that must be adhered to by all employees without exception (Mangkunegara et al. 2015)

- Supervisor: Supervisors are those who have responsibility for ensuring results of a job. In this research, it is the direct supervisor to the subordinate.

- Colleagues: Colleagues are co-workers in the same company, often sharing and communicating with each other in the work.

- Working conditions: Working condition is defined as the actual situation of the working place including the facilities for the job (Bellingham, 2004). The specific characteristics of construction work requires high job security at the working site, high job presure to 
accomplish the work in schedule and strict requirements on work quality. Job satisfaction of the workers related to this context.

- Benefits and Income: Income reflects the amount of money that an individual acquires from their work. In this research, the income of an employee includes basic salary, allowance (if any), different types of periodical and non-periodical incentives, commission (if any) and other monetary benefits occurring from the current job. Stasny (2008) argues that the employee satisfaction on his/her income results from his/her own feeling about the equality of the pay system. Two issues are related. These are appraisals and welfare: the appraisal provides necessary information for employer to make appropriate decision on salary, incentives and promotion (achievement); benefits and welfare includes all the interest that an employee is entitled beside his/her monetary income. Artz (2008) concludes that benefits and welfare play an important role in identifying the satisfaction level of an employee.

\section{Research Methodology and Data Collection}

Both quantitative and qualitative method is applied in this research. Based on secondary data and discussion with the staff, the research developed preliminary measurement items for job satisfaction. The 5 point Likert scale is utilized in measuring the variables. The measurement scale applied for observation, independent and dependent variables in the research is 5 point Likert scale: 1 strongly disagree, 2 disagree, 3 neutral, 4 agree, 5 strongly agree.

Out of 220 questionnaires sent out, 192 were collected equivalent to $87.3 \%$. 155 respondents are usable. The questionnaires were sent directly to those who are working in the public technology universities in Vietnam. The respondents are staff who work at different functional departments (admin, planning and accounting, personnel, etc.) with more than 1year labor contract. The usable questionnaire rate of response was $80.7 \%$. These response rates are acceptable as compared with previous researches.

\section{Sample Characteristics}

There are $25.5 \%$ male respondents and $74.5 \%$ of female respondents. In general, female staff often outnumber staff work in admin job. Most respondents are aged from 30-50 (85.8\%), respondents are aged $<30$ and $>50$ is accounted for $6.5 \%$ and $7.7 \%$ respectively. The percentage of $>5$-year seniority is $86.5 \%$, whereas the number of $<5$-year-seniority is $13.5 \%$. $45.8 \%$ respondents have under and post graduate educational level and $53.5 \%$ have college educational level and only $0.7 \%$ have an intermediate educational level. $18.1 \%$ respondents are managers; $81.9 \%$ respondents are non-managers.

\section{Data Analysis}

SPSS20.0 software is used to analyze the data. The main statistical tools including factor analysis, ANOVA, multiple regressions are used to analyze the data. First, factor analysis is used to reduce the number of variables to more manageable sets, to find the underlying factors in the data and to help to evaluate the validity of measures in the real situation. Then, multiple regressions are used to estimate the relationships between the independent variables and the dependent variables. Besides, exploratory factor analysis (EFA) and Cronbach's alpha value for testing the reliability and validity of scale are applied in this research.

\section{Reliability Data}

49 variables are analyzed under the rule of Eigenvalue, of which 7 factors are extracted $(>1)$, covering $73.37 \%$ of the variation. The value of KMO is equal to $0.923(>0.5)$, which serves as a condition for the factor analysis. The variables as "Working places are on the safe 
conditions", "University creates a favorable condition for capable admin staff", "Welfares paid by university are important to staff", "I understood my job", "Reasonable workload division", "University provides training for improving staff competencies"; "Fully receiving feedback on performance results", "Useful training for my job" were removed because of the loading is $<0.5$. The remaining 41 variables are put into analysis. 7 factors resulted and accounted for $75.68 \%$ of variance. The value of KMO is equal to $0.922(>0.5)$, which is acceptable (see Appendix 1). Reliability of 7 factors is presented in Table 2.

Table 2 Reliability of Determinants

\begin{tabular}{|l|l|l|}
\hline \multicolumn{1}{|c|}{ Determinants } & Number of variables & Cronbacht's Alpha \\
\hline Reward and discipline (X1) & 8 & 0.960 \\
\hline Income (X2) & 12 & 0.941 \\
\hline Supervisor (X3) & 6 & 0.932 \\
\hline Colleagues (X4) & 3 & 0.881 \\
\hline Working environment and condition (X5) & 4 & 0.803 \\
\hline Job nature (X6) & 3 & 0.754 \\
\hline Benefits and welfare (X7) & 3 & 0.805 \\
\hline
\end{tabular}

\section{Research Results and Discussion}

\section{Job Satisfaction of Administrative Staff in Public University}

$78.06 \%$ respondents overall satisfied with the job, $0.65 \%$ respondents dissatisfied with the job. Similarly, $80.6 \%$ respondents agree and strongly agree with the statement that «Overall, I like my current job ». Findings show that admin staff in Vietnamese public university have a motivation to work, are satisfied with job and like doing their current jobs. (refer to Table 3)

Table 3. Job Satisfaction of Administrative Staff in Public University

\begin{tabular}{|c|c|c|c|c|c|c|c|c|}
\hline Criteria & $\mathbf{N}$ & $\begin{array}{l}\text { Totally } \\
\text { disagree }\end{array}$ & Disagree & & Agree & $\begin{array}{l}\text { Totally } \\
\text { agree }\end{array}$ & $\mathbf{N}$ & Mean \\
\hline \multirow{2}{*}{$\begin{array}{l}\text { I am } \\
\text { satisfied } \\
\text { with my } \\
\text { job, overall }\end{array}$} & $\mathrm{N}$ & 0 & 1 & 33 & 99 & 22 & 155 & \multirow[b]{2}{*}{3,916} \\
\hline & $\%$ & - & 0.65 & 21.29 & 63.87 & 14.19 & 100 & \\
\hline \multirow{2}{*}{$\begin{array}{l}\text { I like my } \\
\text { current job, } \\
\text { overall }\end{array}$} & $\mathrm{N}$ & 0 & 1 & 29 & 87 & 38 & 155 & \multirow[b]{2}{*}{4,045} \\
\hline & $\%$ & - & 0.65 & 18.71 & 56.13 & 24.52 & 100 & \\
\hline
\end{tabular}

This result is almost the same with the results of Thuy (2011) research on the factors that influence on job satisfaction (the average score of 3.36) and the results of Anh (2010) research on measuring the job satisfaction with an average of job satisfaction score of 3.41.

\section{Relationships Between Determinants of Job Satisfaction and Administrative Staff's Job Satisfaction}

Table 4 shows the tolerance of determinants are quite high with the value $>0.5$ and the variance inflation factor $(\mathrm{VIF})<10$. It is confirmed that there is no multi-collinearity in this model. 
Table 4: Regression Result of Determinants Influencing on Job Satisfaction

\begin{tabular}{|c|c|c|c|c|c|c|c|}
\hline \multirow[t]{2}{*}{ Model $^{\mathbf{a}}$} & \multicolumn{2}{|c|}{$\begin{array}{l}\text { Unstandardized } \\
\text { Coefficients }\end{array}$} & \multirow{2}{*}{$\begin{array}{l}\text { Standardiz } \\
\text { ed } \\
\text { Beta } \\
\end{array}$} & \multirow[t]{2}{*}{$\mathbf{T}$} & \multirow[t]{2}{*}{ Sig. } & \multicolumn{2}{|c|}{$\begin{array}{l}\text { Collinearity } \\
\text { Statistics }\end{array}$} \\
\hline & B & Std.Error & & & & Toleran & VIF \\
\hline 1 (Constant) & $\begin{array}{l}5.070 \mathrm{E} \\
\mathbf{1 .}\end{array}$ & .050 & & .000 & 1.000 & 1.000 & 1.000 \\
\hline Rewards and discipline (X1) & .266 & .050 & .266 & 5.279 & .000 & 1.000 & 1.000 \\
\hline Income (X2) & .316 & .050 & .316 & 6.273 & .000 & 1.000 & 1.000 \\
\hline Supervisor (X3) & .348 & .050 & .348 & 6.925 & .000 & 1.000 & 1.000 \\
\hline Colleagues (X4) & .165 & .050 & .165 & 3.275 & .001 & 1.000 & 1.000 \\
\hline $\begin{array}{l}\text { Working environment and } \\
\text { mnnditinns ( }\end{array}$ & .494 & .050 & .494 & 9.825 & .000 & 1.000 & 1.000 \\
\hline Job nature (X6) & .231 & .050 & .231 & 4.590 & .000 & 1.000 & 1.000 \\
\hline Benefits and welfare (X7) & .106 & .050 & .106 & 2.112 & .036 & 1.000 & 1.000 \\
\hline $\mathrm{R}=.792$ & 28 & isted $\mathrm{R}^{2}=$ & 10 & & g. $=$ & & \\
\hline
\end{tabular}

a. Dependent var: Job satisfaction

The relationship of determinants and job satisfaction of administrative staff in public university is show in the following equation:

$Y=0.266 X_{1}+0.316 X_{2}+0.348 X_{3}+0.165 X_{4}+0.494 X_{5}+0.231 X_{6}+0.106 X_{7}$

In which, $Y$ : job satisfaction of administrative staff at public university;

$\mathrm{X}_{1}, \mathrm{X}_{2}, \mathrm{X}_{3}, \mathrm{X}_{4}, \mathrm{X}_{5}, \mathrm{X}_{6}, \mathrm{X}_{7}$ : satisfaction of rewards and discipline, income, supervisor, colleagues, working environment and conditions, job nature, and benefits and welfare respectively.

If the satisfaction of reward and discipline increases 1 point, the job satisfaction of admin staff will increase 0.266 while other independent variables keep unchanged. Similarity, if the satisfaction of income, supervisor, colleagues, working environment, job nature and benefits and welfare increases 1 point, job satisfaction of administrative staff in public university will increase $0.316,0.348,0.165,0.494,0.231$ and 0.106 respectively while other determinants keep unchanged.

\section{Hypothesis Testing Result}

\section{Model 1: The Differences of Job Satisfaction by Individual Personality}

The multi regressions result of determinants influencing on job satisfaction of administrative staff in public technology university in Vietnam is presented in Table 4. Adjusted $\mathrm{R}^{2}=.610$ shows that 7 independent variables of this model explained $61.0 \%$ the variance of dependent variable (job satisfaction) and the relevance of this model is acceptable. In addition, $F$ value equal 35.424 with the significant level $<0.05$ ( $\mathrm{sig} .=.000$ ) indicates that the given multi regression model is relevant with the data and usable model. At the significant confidence of $95 \%$, all hypotheses with $\beta_{k}$ value is $>0, \mathrm{p}<0.05$ are strongly supported (see Table 5). It means that 7 determinants including reward and discipline, supervisor, colleagues, income, working environment and conditions, job nature and benefits and welfare have a strong influence on job satisfaction. 
Table ;5 Results of Testing Hypotheses

\begin{tabular}{|l|l|l|}
\hline Hypothesis & $\begin{array}{l}\text { Standardized } \\
\text { coefficients } \\
\text { (Beta) }\end{array}$ & Results \\
\hline $\begin{array}{l}\text { H1: Job nature creates a positive impact on the job } \\
\text { satisfaction of administrative staff in public university in } \\
\text { Vietnam }\end{array}$ & S31 \\
\hline $\begin{array}{l}\text { H2: Reward and discipline create a positive impact on the } \\
\text { job satisfaction of administrative staff in public university } \\
\text { in Vietnam }\end{array}$ & .266 & Supported \\
\hline $\begin{array}{l}\text { H3: Supervisor has a positive impact on the job } \\
\text { satisfaction of administrative staff in public university in } \\
\text { Vietnam }\end{array}$ & .348 & Supported \\
\hline $\begin{array}{l}\text { H4: Colleagues have a positive impact on the job } \\
\text { satisfaction of administrative staff in public university in } \\
\text { Vietnam }\end{array}$ & .165 & Supported \\
\hline $\begin{array}{l}\text { H5: Working environment and conditions create a positive } \\
\text { impact on the job satisfaction of administrative staff in } \\
\text { public university Vietnam }\end{array}$ & .494 & Supported \\
\hline $\begin{array}{l}\text { H6: Income creates a positive impact on the job } \\
\text { satisfaction of administrative staff in public university in } \\
\text { Vietnam }\end{array}$ & .316 & Supported \\
\hline $\begin{array}{l}\text { H7: Benefits and welfare create a positive impact on the } \\
\text { job satisfaction of administrative staff in public university } \\
\text { in Vietnam }\end{array}$ & .106 & \\
\hline
\end{tabular}

Model 2: The Differences of Job Satisfaction by Individual Personality

The independent Sample T-test was used to test the difference of job satisfaction between genders.

Table 6: Comparative Results of The Differences of Job Satisfaction Between Genders

\begin{tabular}{|c|c|c|c|c|}
\hline & & & \multicolumn{2}{|c|}{ Job satisfaction } \\
\hline & & & $\begin{array}{c}\text { t-test for } \\
\text { Equality of }\end{array}$ & $\begin{array}{c}\text { t-test for inequality } \\
\text { of variance }\end{array}$ \\
\hline \multirow{2}{*}{$\begin{array}{l}\text { Levene's test for } \\
\text { Equality of variances }\end{array}$} & \multicolumn{2}{|l|}{$\mathrm{F}$} & .149 & \\
\hline & \multicolumn{2}{|l|}{ Sig } & .694 & \\
\hline \multirow{7}{*}{$\begin{array}{l}\text { t- test for Equality of } \\
\text { Means }\end{array}$} & \multicolumn{2}{|l|}{$\mathrm{T}$} & .316 & .312 \\
\hline & \multicolumn{2}{|l|}{ Df } & 152 & 129.647 \\
\hline & \multicolumn{2}{|l|}{ Sig ** } & .764 & .767 \\
\hline & \multicolumn{2}{|l|}{ Mean difference } & .02077 & .02077 \\
\hline & \multicolumn{2}{|c|}{ Std. Error difference } & .09681 & .09725 \\
\hline & \multirow{2}{*}{\begin{tabular}{|l|}
$95 \%$ \\
confidence \\
intarrants of tha
\end{tabular}} & Lower & -.16045 & -.16061 \\
\hline & & Upper & .21412 & .21702 \\
\hline
\end{tabular}


Table 6 shows the result of t-test $(\mathrm{t}(152)=0.316, \mathrm{p}=0.764>0.05)$, it means that there is no difference of job satisfaction between woman and man at public university in Vietnam. The Hypothesis H8: there is a significant diffrence of job satisfaction of the administrative staff in public university in Vietnam between genders is rejected.

ANOVA is applied to test the differences of job satisfaction of the employees at public university by age, seniority, and educational level.

Table 7: Summary of One-way ANOVA test

\begin{tabular}{|c|c|c|c|c|c|c|}
\hline $\begin{array}{l}\text { Individual } \\
\text { Personality }\end{array}$ & \multicolumn{4}{|l|}{ Mean } & $\mathbf{F}$ & Sig. \\
\hline Gender & \multicolumn{2}{|l|}{$\begin{array}{l}\text { Male } \\
3.23\end{array}$} & \multicolumn{2}{|c|}{$\begin{array}{l}\text { Female } \\
\text { 3.30 }\end{array}$} & .149 & .694 \\
\hline Age & $\begin{array}{l}<30 \\
3.47\end{array}$ & $\begin{array}{l}\text { From 30-50 } \\
3.38\end{array}$ & & $\begin{array}{l}>\mathbf{5 0} \\
3.54\end{array}$ & .617 & .554 \\
\hline Seniority & $\begin{array}{l}<1 \text { year } \\
3.37\end{array}$ & $\begin{array}{l}\text { 1-5 years } \\
3.10\end{array}$ & & $\begin{array}{l}>5 \text { years } \\
3.46\end{array}$ & .395 & .774 \\
\hline $\begin{array}{l}\text { Educational } \\
\text { level }\end{array}$ & $\begin{array}{l}\text { College } \\
3.40\end{array}$ & $\begin{array}{l}\text { Undergradu } \\
3.21\end{array}$ & ate & $\begin{array}{l}\text { Post-graduate } \\
3.11\end{array}$ & 1.945 & .038 \\
\hline
\end{tabular}

Table 7 shows the result of ANOVA test of job satisfaction between genders, by age, by senority, and by educational level.

The $F(148)=.617, p=.554>0.05$ shows that there is no difference of job satisfaction of the administrative staff by age. Hypothesis H9: There is a difference in job satisfaction of administrative staff by age in public university in Vietnam. H9 is rejected.

The $F(148)=.395, p=.774>0.05$ shows that there is no difference of job satisfaction of the administrative staff by seniority. The hypothesis H10: There is a difference in job satisfaction of administrative staff by seniority in public university in Vietnam. H10 is rejected is rejected.

The $F(148)=1.945, p=.0 .038<0.05$ shows that there is a difference of job satisfaction of the employee by educational level. Hypothesis H11: there is a difference of job satisfaction of the administrative staff by educational level at public univerisity in Vietnam is accepted. It means that there is a difference of job satisfaction of the administrative staff by educational level at public university in Vietnam.

Table 8: Summary Results of Model 2

\begin{tabular}{|l|l|}
\hline Hypothesis & Results \\
\hline $\begin{array}{l}\text { H8: There is a difference in job satisfaction of administrative staff between } \\
\text { genders in public university in Vietnam. }\end{array}$ & Rejected \\
\hline $\begin{array}{l}\text { H9: There is a difference in job satisfaction of administrative staff by age in } \\
\text { public university in Vietnam. }\end{array}$ & Rejected \\
\hline $\begin{array}{l}\text { H10: There is a difference in job satisfaction of administrative staff by } \\
\text { seniority in public university in Vietnam. }\end{array}$ & Rejected \\
\hline $\begin{array}{l}\text { H11: There is a difference in job satisfaction of administrative staff by } \\
\text { educational level in public university in Vietnam. }\end{array}$ & ACCEPTED \\
\hline
\end{tabular}




\section{Discussion}

Administrative staff in public university are overall satisfied with their job. They have a motivation to do their job. Job satisfaction of administrative staff in Vietnamese public university has a mean of 3.916 (> average of 2,5) and the like doing their job has a mean of 4.045 (> average 2,5). This result is almost the same with the results of Thuy (2011) research on the factors that influence on job satisfaction (the average score of 3.36) and the results of Anh (2010) research on measuring the job satisfaction with an average of job satisfaction score of 3.41.

There are 7 determinants of job satisfaction of administrative staff in public university. The determinant's importance of influence is expressed in Table 9. This result is almost the same with the results of Toan (2009), Anh (2010), Thuy (2011), and Ngoc (2013). However, ranking of the important factors of this research is different with previous research. The main reason is that the past research focused on the job satisfaction of workers, and this research focused on studying the job satisfaction of administrative staff at university. The characteristics of administrative job and university environment are different with business environment. This research identifies that "Working environment and conditions" has a strongest impact $(25.65 \%)$, following is "supervisor" $(18.01 \%)$, the lowest is "benefits and welfare" $(5.57 \%)$.

Table 9. Ranking of Components of Administrative Staff's Job Satisfaction in Public University

\begin{tabular}{|l|l|l|l|}
\hline Components of job satisfaction & $\begin{array}{l}\text { Standardized coefficients } \\
\text { (Beta) }\end{array}$ & \% & Rank \\
\hline Working conditions (X5) & .494 & 25.65 & 1 \\
\hline Supervisor (X3) & .348 & 18.01 & 2 \\
\hline Income (X2) & .316 & 16.41 & 3 \\
\hline Reward and discipline (X1) & .266 & 13,80 & 4 \\
\hline Job characteristics (X6) & .231 & 11.99 & 5 \\
\hline Colleagues (X4) & .165 & 8.57 & 6 \\
\hline Benefits and welfare (X7) & .106 & 5.57 & 7 \\
\hline Sum & $\mathbf{1 . 9 2 6}$ & $\mathbf{1 0 0}$ & \\
\hline
\end{tabular}

Findings show that the higher level of job satisfaction administrative staff has, the more motivation in doing their job. Motivation in work of administrative staff in public university is their passion and voluntary to enhance efforts to achieve the personal goals and university goals. There is no difference of job satisfaction of administrative staff between gender, by age, by seniority in public university in Vietnam with the significant confidential level of 95\% ( $>0.05$ ). However, this is a clear difference of job satisfaction in educational levels of administrative staff in public university in Vietnam. The higher level of educated administrative staff have the less of job satisaction. Administrative staff with postgraduate degree has the lowest level of job satisfaction. Administrative staff who have a college degree have the highest level of job satisfaction. This also a significant point which the employers should pay attention to and should have different ways to motivate their staff with different levels of education such as using financial and non-financial incentives to motivate them accordingly.

\section{Conclusion}

The results show the key factors related to job satisfaction. The leaders and managers of public university in Vietnam should focus on working conditions, develop supervisor's 
capability, and have fair income to enhance the job satisfaction. As the results, if the administrative staff are more satisfied with job, they will engage longer with the university. In order to motivate administrative staff to work, it is necessary to develop and apply efficiently and effectively the human resources management policy system, effective measures and good management practices to create higher level of job satisfaction and strengthen their long-term contribution to the university. Some suggestions to public technology universities in Vietnam are given as follows:

- University should invest in facilities, office room, modern equipment and IT infrastructure to reduce the bureaucratic task and paper works to improve the efficiency and effectiveness of administrative jobs.

- The supervisors should always support and give feedback to the subordinates. They also should recognize and reward the administrative staff's efforts and results. They should listen to the voice of administrative staff and take a good care for them, recognize the competent staff and encourage their innovations and creativity.

- The university should have a fair pay system. Especially in the process of selffinance, the university should use KPI (Key Performance Indicators) in performance appraisal. It will help the administrative staff feel more satisfied with their contribution and efforts to the university.

- Highly educated administrative staff usually are a key resource of the university. They will operate and master the administration and other logistics process and bring the effectiveness and efficiency of the university. It is necessary for the university to develop an excellent strategy to keep and develop this kind of admin staff such as standardization of the salary, awarding on time, enriching jobs, enhancing the career development for the staff by offering training and promoting for the best administrative staff.

Application of each solution will depend on the particularity and conditions of each public university. Public technology university in Vietnam should improve the job satisfaction of their admin staff because it is limited.

\section{References}

Anh, N.T.K (2010), Employee's satisfaction measurement at Fresenius Kabi Bidiphar JSC., Master research.

Artz, Benjamin (2008), Fringe benefit and job satisfaction, University of Wisconsin - White water, USA.

Andrew Oswald (2002), Are you happy at work? Job satisfaction and work-life balance in the US and Europe, Professor of Economics, University of Warwick Coventry, CV4 7AL, England.

Bellingham, R. (2004), Job satisfaction survey, Wellness Council of America.

Binh, N.T.T (2009), Employee's satisfaction measurement at Long An Mechanics JSC., Master research.

Crossman, A. \& Bassem, A.Z. (2003). Job satisfaction and employee performance of Lebanese banking staff. Journal of Managerial Psychology. 18. 368-376

Dung, T.T.K. (2005), Job satisfaction measurement in Vietnamese condition, Technology and Science Development Journal, HCMC National University.

Ellickson, C. M. \& Logsdon, K. (2001). Determinants of Job Satisfaction of Municipal Government Employees. State and Local Government Review. 33. 173-184.

GSO, 2017

Hackman, J. R., \& Oldham, G. R. (1975). Development of the Job Diagnostic Survey. Journal of Applied Psychology, 60(2), 159-170. 
Jex, S.M., \& Guadnowski, D.M. (1992). Efficacy beliefs and work stress. Journal of Organizational Behavior, 13, 509-517. Jones, M.V., \& Coviello, N.E. (2005).

Kreitner, R and Kinicki, A (2007), Organizational Behavior, McGraw Hill Irwin.

Locke, E.A. (1976), The nature of job satisfaction. In M.D.Dunnette (Ed), Handbook of industrial and organizational, Chicago, USA.

Luddy, Nezaam (2005), Job Satisfaction amongst Employees at a Public Health Institution in the Western Cape, University of Western Cape, South Africa.

Mangkunegara, A.P., Octorend, T. R. (2015), Effect of work disciplines, work motivation and job satisfaction on employee organizational commitment in the company (case study in PT. Dada Indonesia), Universal Journal of Management 3(8):318-328, DOI: 10.13189/ujm.2015.030803

Ngoc, P.T.K, Nguyet, H.A. (2013), Job satisfaction at South Korean Construction Companies in Vietnam, in Proceedings of The International Conference on Economic Challenges - Improving SMEs' Competitiveness, Sep 2013, ISBN: 978-604-938-723-4

Ngoc, P.T.K. (2019), Determinants of job satisfaction: A case study of admin staff in Vietnam's public university, in Proceedings of The International Conference on Business, Management, Technology and Education (ICBMTE 2019) $23^{\text {rd }}$ and $24^{\text {th }}$ March 2019. Ancasa Residences, Port Dickson, Malaysia eISBN: 978-967-16956-0-9, pp.47-59

Nhat, N.D.V. (2009), relationship of job satisfaction on the staff efforts and loyalty in telecom industry in Vietnam, Master research.

Rafiq, M., Javed, M., Khan, M. \& Ahmad, M. (2012), Effect of rewards on job satisfaction: Evidence from Pakistan, Interdisciplinary Journal of contemporary research business, Vol.4, No.1, 337-347

Stasny, Kimberly, "How do clinical social workers stay enthusiastic about their work?" (2008). Theses, Dissertations, and Projects. 1265. https://scholarworks. smith.edu/theses/1265

Spector, P.E. (1997), Job Satisfaction Among Employee Assistance Program Professionals in United States, Virginia Polytechnic Institute and State University, Virginia, USA

Spector, P. E. (1988). Development of the Work Locus of Control Scale. Journal of Occupational Psychology, 61(4), 335-340. http://dx.doi.org/10.1111/j.20448325.1988.tb00470.x

Thuy, T.T.T (2011), Studying factors influencing on job satisfaction of lecturers in HCMC, Master research.

Toan, C.V. (2009), Factors influencing on job satisfaction of admin staff in HCMC, Master research.

Vroom, V.H. (1964), Work and motivation. New York: Wiley.

Trines, S. (2017), Education in Vietnam, Asian Pacific, Wenr, https://wenr.wes.org/2017/11/education-in-vietnam

Weiss, D.J., Dawis, R.V., England, G.W. and Lofquist, L.H. (1967), Manual for the Minnesota Satisfaction Questionnaire: "Minnesota studies in vocational rehabilitations". Minneapolis: Industrial Relations Center, University of Minnesota. http://giaoduc.net.vn/Giao-duc-24h/Viet-Nam-da-vuot-so-luong-truong-dai-hoc-theomuc-tieu-de-ra-post193670.gd 